\section{Nitrate Leaching Potential under Variable and Uniform Nitrogen Fertilizer Management in Irrigated Potato Systems}

\author{
K.M Whitley and

\section{J.R Davenport}

\begin{abstract}
Additional IndeX WORDs. Solanum tuberosum, ion exchange membrane, landscape position, soil organic matter, spatial variability
\end{abstract}

Summary. Potato (Solanum tuberosum) production in Washington State's Central Columbia Plateau faces nitrogen $(\mathrm{N})$ management challenges due to the combination of coarse textured soils (sandy loam to loam) and hilly topography in this region as well as the high $\mathrm{N}$ requirement of potato. Potato growth and development can vary with the $\mathrm{N}$ availability across the field. In this 2-year study, two adjacent potato fields were selected each year (1999 and 2000). Each field was soil sampled on a $200 \times 200 \mathrm{ft}$ $(61.0 \mathrm{~m})$ grid to establish existing soil $\mathrm{N}$ content. One field was preplant fertilized with variable $\mathrm{N}$ rate while the other was conventionally preplant fertilized, applying a uniform rate across the field based on the field average. During the growing season, each field was monitored for nitrate leaching potential using ion exchange membrane technology. Soil and plant nutrient status were also monitored by collecting in-season petiole and soil samples at two key phenological stages, tuber initiation and tuber bulking. Overall this research showed that variable rate preplant $\mathrm{N}$ fertilizer management reduced $\mathrm{N}$ leaching potential during the early part of the growing season, but did not persist the entire season. Since preplant $\mathbf{N}$ accounted for only $40 \%$ of the total seasonal $\mathrm{N}$ applied, it is possible that further gains could be made with variable rate in-season $\mathrm{N}$ application or with variable rate water application.

Department of Crops and Soil Science Washington State University, Prosser, WA 99350.
T he Central Columbia Plateau of Washington State was the focus of a water quality study because of its high-risk for nitrate leaching potential (Fuhrer et al., 1999). The Central Columbia Plateau is an arid to semiarid region, receiving 5.9 to 7.9 inches $(15$ to $20 \mathrm{~cm}$ ) of rainfall peryear, most of which occurs in the winter. The southwest subunit of the Central Columbia Plateau, Quincy-Pasco subunit, receives the majority of the irrigation in this region. With the introduction of irrigation the recharge rate of the water table increased and raised the water table 10 to $100 \mathrm{ft}$ ( 3.0 to $30.5 \mathrm{~m}$ ) (Williamson et al., 1998). Currently, the Central Columbia Plateau supports field crops such as potatoes, corn ( $Z e a$ mays), alfalfa (Medicago sativa), as well as orchards and cereal grains. Forty years after the introduction of irrigation to the region, about $20 \%$ of the wells tested in this region exceeded the maximum allowable limit of $10 \mathrm{ppm}$ $\left(\mathrm{mg} \cdot \mathrm{kg}^{-1}\right)$ nitrate- $\mathrm{N}\left(\mathrm{NO}_{3}-\mathrm{N}\right)$ (Fuhrer et al., 1999). Further investigation of this region showed that the wells that had high $\mathrm{NO}_{3}-\mathrm{N}$ concentrations in test samples occurred in the Quincy-Pasco subunit, which receives both the highest irrigation and $\mathrm{N}$ fertilizer inputs in the area.

Potato has a high $\mathrm{N}$ requirement, up to $300 \mathrm{lb} /$ acre $\left(336.2 \mathrm{~kg} \cdot \mathrm{ha}^{-1}\right)$ for a 30 tons/acre $\left(67.2 \mathrm{Mg} \cdot \mathrm{ha}^{-1}\right)$ expected yield (Lang et al., 1999) and is sensitive to soil moisture stress (Roberts and Cheng, 1988; Prunty and Greenland, 1997). The rooting depth of the potato is very shallow, with few roots extending 24 inches $(61.0 \mathrm{~cm})$ below the soil surface (Kunkel and Thornton, 1986; Pan and Hiller, 1992; Stalham and Allen, 2001). The combination of high irrigation and $\mathrm{N}$ requirements and shallow rooting depth of potato results in high $\mathrm{NO}_{3}-\mathrm{N}$ leaching risk in potato production (Roberts et al., 1991). Potato has been associated with high $\mathrm{NO}_{3}-\mathrm{N}$ leaching potential for many years and much work has been done to find ways to reduce that potential. Applying all of the $\mathrm{N}$ fertilizer preplant leads to early season nitrate leaching and potential late season $\mathrm{N}$ deficiency. In addition, as the potato plant is establishing early in the growing season little $\mathrm{N}$ is required, further increasing the potential for excess $\mathrm{N}$ (Errebhi et al., 1998). Split applications of $\mathrm{N}$ have shown reduced leaching potential and reduced crop stress (King et al., 1999;
Roberts and Cheng, 1985; Prunty and Greenland, 1997).

Integrating site specific management (SSM) with split applications of $\mathrm{N}$ fertilizer has the potential to further reduce $\mathrm{NO}_{3}-\mathrm{N}$ leaching. Rather than treating a whole field as a uniform unit by fertilizing at one rate, SSM allows fertilizer to be applied variably. Dampney et al. (1999) found a reduction in $\mathrm{NO}_{3}-\mathrm{N}$ leaching in winter wheat (Triticum asetivum) when comparing uniform rate (UR) and variable rate (VR) $\mathrm{N}$ fertilizer application. SSM of $\mathrm{N}$ fertilizer on corn decreased the amount of $\mathrm{N}$ in the soil profile at the end of the season compared with UR fertilizer (Kitchen et al., 1995). Previous studies of SSM and VR fertilizer application have focused on non-irrigated low value crops such as wheat and corn. In irrigated potatoes there are the unique issues of the irrigation requirement and the shallow root zone to consider. Excess $\mathrm{NO}_{3}-\mathrm{N}$ present in the root zone with irrigation application creates a potential for $\mathrm{NO}_{3}-\mathrm{N}$ leaching.

With this combination of characteristics it is common for water and $\mathrm{NO}_{3}-\mathrm{N}$ to accumulate in the valley positions and for nitrate leaching to occur in these zones due to excess water (Fransen et al., 1996). The Central Columbia Plateau has a variable topography with field elevation changes ranging from 16.4 to 164.0 $\mathrm{ft}(5$ to $50 \mathrm{~m})$. This variability makes uniform water penetration difficult (Evans et al., 1996). Knoll positions tend to be drier and have a low $\mathrm{NO}_{3}-\mathrm{N}$ leaching potential. Research focusing on canola (Brassica napus) yield response to $\mathrm{N}$ within landscape classes found a fertility difference along the slope and variable yield response to $\mathrm{N}$ (Nolan et al., 1999). Nitrogen could be managed differently within landscape classes to achieve better $\mathrm{N}$ use efficiency and reduce $\mathrm{NO}_{3}-\mathrm{N}$ leaching potential. Organic matter content has also been shown to be related to landscape position and $\mathrm{N}$ level in the soil (Franzen et al, 1996) with higher $\mathrm{N}$ level associated with higher organic matter. Although the soils in the central Columbia Plateau have a relatively low organic matter there is still potential for leaching due to irrigation.

The objective of this project was to examine how preplant $\mathrm{N}$ fertilizer management (UR versus VR fertilizer application) and inherent field condi- 
tions (landscape position, soil organic matter) affect $\mathrm{NO}_{3}-\mathrm{N}$ leaching in an irrigated potato cropping system.

\section{Materials and methods}

This study was conducted in 1999 and 2000 on a commercial farm in southeastern Washington (lat. $45^{\circ}$ 59' 17" N, long. $119^{\circ} 08^{\prime} 39^{\prime \prime} \mathrm{W}$ ) on a soil mapped as Hezel loamy fine sand (coarse-loamy, mixed, nonacidic, mesic, Typic Torriorthents). Each year, two neighboring fields were used, for a total of four fields over the course of the study. In both years, two fields were soil sampled preplant to a depth of 12 inches $(30.5 \mathrm{~cm})$ on a $200 \times 200$-ft georeferenced grid. Samples were analyzed for $\mathrm{NO}_{3}-\mathrm{N}$ and ammonium-N $\left(\mathrm{NH}_{4}-\right.$ N) (Redulla et. al, 2002). The results were used to calculate the amount of fertilizer to be applied. In each year, $\mathrm{N}$ fertilizer was applied preplant to one field at a uniform rate (UR) and the other field at a variable rate (VR). For the VR treatment, fertilizer rates across the field were varied based on the amount of soil inorganic $\mathrm{N}$ integrated across the field with commercial software and equipment (Anderson et al., 1997), whereas for the UR treatment the single rate was based on the average of all the samples. Preplant fertilizer N rate was calculated from the estimated total in season crop $\mathrm{N}$ requirement. The regional crop requirement for a potential yield of 30 to 35 tons/acre (67.2 to $78.4 \mathrm{Mg} \cdot \mathrm{ha}^{-1}$ ) crop of 'Russet Burbank' is $350 \mathrm{lb} /$ acre (392.3 $\mathrm{kg} \cdot \mathrm{ha}^{-1}$ ) (Lang et al., 1999). In 2000 an adjustment to the fertilizer recommendation accounts for the variety change. At preplant, $40 \%$ of the total in season $\mathrm{N}\left[142 \mathrm{lb} / \operatorname{acre}\left(159.2 \mathrm{~kg} \cdot \mathrm{ha}^{-1}\right)\right]$ minus the $\mathrm{N}$ credits from soil inorganic $\mathrm{N}$ was applied as described above for $\mathrm{VR}$ and UR treatments. The remaining $214 \mathrm{lb} /$ acre $\left(239.9 \mathrm{~kg} \cdot \mathrm{ha}^{-1}\right)$ were applied through the irrigation system at the grower's discretion throughout the growing season at a uniform rate in all fields for both years. The Columbia River was the source for the irrigation water and has no detectable nitrate to contribute to the $\mathrm{N}$ application. Irrigation was also under the control of the grower applying typically the same amount to each field both years.

The potato variety planted was 'Russet Burbank' in 1999 and 'Shepody' in 2000 . The disparity in variety was related to this study site being part of a long term study on a commercial farm where the grower and processor made the decision on variety planted. 'Russet Burbank' potatoes are a long season variety requiring a 140 - to $150-\mathrm{d}$ growing season, where as, 'Shepody' is an earlier maturing variety with a shorter ( 100 to $110 \mathrm{~d}$ ) growing season. Since there are distinct differences between the two varieties, the data from each year were analyzed separately.

The hilly topography and high $\mathrm{N}$ applications suggest a high potential for $\mathrm{N}$ movement both vertically and horizontally along the landscape. Monitoring sites for this study were chosen to best evaluate $\mathrm{N}$ movement throughout the growing season. The monitoring sites were chosen to reflect different levels of soil organic matter content (SOM) and landscape positions (knoll, slope, valley). There was no difference in SOM content between fields. SOM levels were chosen to be $\operatorname{high}[\mathrm{H}(>1 \%)]$ and low $[\mathrm{L}(<1 \%)]$. The median SOM level for the fields was $1 \%$ for 1999 and $1.1 \%$ for 2000 . The $1 \%$ SOM became the deciding factor or high and low. A map of the elevation and SOM were created from the original data points on the 200 -ft grid in ArcView (ESRI, Redlands, Calif.) using inverse distance weighting. By overlaying these maps the monitoring sites were selected based on the guidelines for landscape position and SOM. Each landscape position (LP)/SOM site combination was replicated three times resulting in a total of 18 monitoring sites per field. The monitoring sites spanned the field and were $200 \mathrm{ft}$ to $400 \mathrm{ft}$ (61.0 to $121.9 \mathrm{~m})$ apart.

Ion exchange membrane probes, Plant Root Simulators (PRS; Western Ag Innovations Inc., Saskatoon, Sask.) were also placed at each monitoring site at 8 inches $(20.3 \mathrm{~cm})$ and 24 inches $(61.0 \mathrm{~cm})$. Both anion $\left(\mathrm{NO}_{3}-\right.$ $\mathrm{N})$ and cation $\left(\mathrm{NH}_{4}-\mathrm{N}\right)$ specific PRS probes were used to track all soluble N (Qian and Schoenau, 2000). PRS probes were exchanged weekly at approximately the same time of day beginning at row closure and ending about three weeks prior to harvest. The values derived from the PRS reflect a total availability of $\mathrm{NO}_{3}-\mathrm{N}$ across the week that the probes were in situ. PRS probes were taken to the lab, extracted with $20 \mathrm{~mL}(0.74 \mathrm{oz}$.) of $0.5 \mathrm{~m}$ hydrochloric acid (Qian et al., 1992) and analyzed for $\mathrm{NO}_{3}-\mathrm{N}$ (Environmental Protection Agency, 1984b) and $\mathrm{NH}_{4}-\mathrm{N}$ (Environmental
Protection Agency, 1984a). The extract concentration was multiplied by 20 to account for the extraction then divided by the surface area of the probe's resin $\left[17.5 \mathrm{~cm}^{2}\left(2.71\right.\right.$ inch $\left.\left.^{2}\right)\right]$ resulting in units of $\mu \mathrm{g} \cdot \mathrm{cm}^{-2}\left(2.4 \times 10^{-7} \mathrm{oz} / \mathrm{inch}^{2}\right)$, which was considered a $\mathrm{NO}_{3}-\mathrm{N}$ availability index.

Two key phenological stages of potato development, tuber initiation and tuber bulking, were chosen for collecting petiole tissue samples and soil samples at surface ( 0 to 12 inches $(30.5 \mathrm{~cm})$ and subsurface (12 to 24 inches) depths for each monitoring site. These growth stages were chosen since they are associated with high $\mathrm{N}$ demand (Lang et al., 1999). Tuber initiation samples were taken 16 weeks preharvest in 1999 and 7 weeks preharvest in 2000. Tuber bulking samples were taken 10 weeks preharvest in 1999 and 3 weeks preharvest in 2000. Petioles were water extracted and analyzed for $\mathrm{NO}_{3}-\mathrm{N}$ and the soil samples were extracted and analyzed for both $\mathrm{NO}_{3}-\mathrm{N}$ and $\mathrm{NH}_{4}-\mathrm{N}$ by a commercial soil and plant test lab.

Each year the fields were soil sampled postharvest to a depth of 12 inches at the original $200 \times 200$-ft georeferenced grid by a commercial soil test lab just as was done preplant. 'Russet Burbank' potato vines had naturally senesced by harvest whereas Sheopdy were green harvested with no vine kill. Regardless of variety post harvest soil sampling reflects the impact of vine incorporation and mineralization in the soil. The samples were analyzed for $\mathrm{NO}_{3}-\mathrm{N}$ and $\mathrm{NH}_{4}-\mathrm{N}$ concentration (Redulla et al., 2002) to evaluate residual soil N. Data from each year was analyzed separately to account for cultivar effects. Statistical analysis of the data was performed using the PROC GLM procedures of PC SAS (SAS Institute, Cary, N.C.).

\section{Results and discussion}

PRS MEASURED SOLUBLE $\mathrm{NO}_{3}$ N. Cumulative $\mathrm{NO}_{3}-\mathrm{N}$ availability index was calculated by combining weekly PRS $\mathrm{NO}_{3}-\mathrm{N}$ values. In 1999, the soil surface position cumulative $\mathrm{NO}_{3}-\mathrm{N}$ availability index was significantly higher in the VR fertilized field $($ mean $=1612.65 \mathrm{ppm})$ compared to the UR (mean $=1089.01 \mathrm{ppm})$ field $(P=0.0003)$. However, in 2000 the cumulative $\mathrm{NO}_{3}-\mathrm{N}$ availability index in the surface soil was significantly lower in the VR $($ mean $=607.92 \mathrm{ppm})$ than 

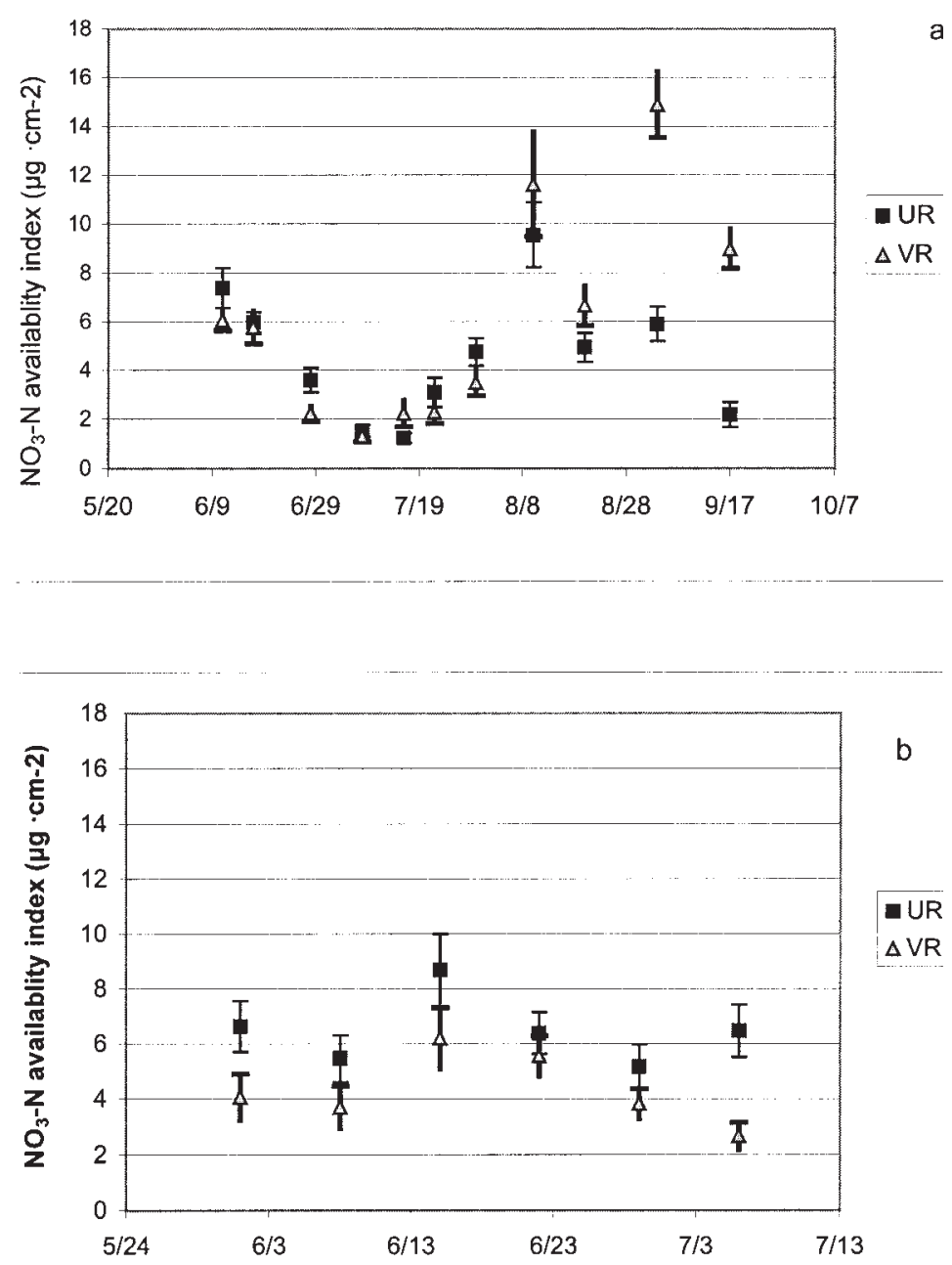

Fig. 1 (above). Effect of UR (uniform rate) and VR (variable rate) preplant fertilizer application to potato on weekly nitrate-nitrogen $\left(\mathrm{NO}_{3}-\mathrm{N}\right)$ availability index averaged across both surface [ 0 to 12 inches $(30.5 \mathrm{~cm})]$ and subsurface [12 to 24 inches $(61.0 \mathrm{~cm})$ ] depths for a) 1999 and b) 2000. Data are averages of 18 points across a field and bars indicate plus and minus $1 \mathrm{SE}\left(1.0\right.$ inch $^{2}=6.45$ $\left.\mathrm{cm}^{2}, 1 \mu \mathrm{g} \cdot \mathrm{cm}^{-2}=2.4 \times 10^{-7} \mathrm{oz} / \mathrm{inch}^{2}\right)$.

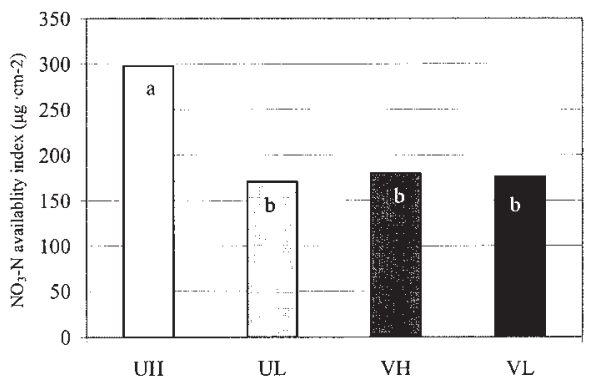

Fig. 2. Effect of preplant fertilizer treatment [U (uniform rate), V (variable rate) $]$ and soil organic matter $[\mathrm{H}$ (high), L (low)] on cumulative soil nitrate-nitrogen $\left(\mathrm{NO}_{3}-\mathrm{N}\right)$ availability index in the subsurface [ 8 to 24 inches $(20.3$ to $61.0 \mathrm{~cm})]$ in potato in 2000. Different letters on bars indicate statistically different values by depth $\left(1.0\right.$ inch $^{2}=6.45 \mathrm{~cm}^{2}, 1$ $\mu \mathrm{g} \cdot \mathrm{cm}^{-2}=2.4 \times 10^{-7} \mathrm{oz} /$ inch $\left.^{2}\right)$. in the UR $($ mean $=881.96 \mathrm{ppm})$ treatment $(P=0.0007)$. Despite the differences in the surface soil plant available $\mathrm{NO}_{3}-\mathrm{N}$, there was no significant difference in the cumulative $\mathrm{NO}_{3}-\mathrm{N}$ availability index in the subsurface depth in either year. Neither UR nor VR negatively impacted the $\mathrm{NO}_{3}-\mathrm{N}$ leaching potential measured by the $\mathrm{NO}_{3}-\mathrm{N}$ availability index.

The growing season length played a role in the $\mathrm{NO}_{3}-\mathrm{N}$ availability index. For the first 6 weeks of monitoring in both years, the VR fertilized fields had lower total $\mathrm{NO}_{3}-\mathrm{N}$ availability indexes (Fig. 1) averaged across landscape position and SOM. In 1999, when the monitoring continued for 15 weeks, the PRS $\mathrm{NO}_{3}-\mathrm{N}$ increased under the VR treatment and was greater than under UR during the final 6 weeks (Fig. 1). This could be related to early tis- sue deterioration in combination with excess irrigation increasing the $\mathrm{NO}_{3}-\mathrm{N}$ availability index. In 'Russet Burbank', this increase in the last 6 weeks skewed the cumulative and average data increasing the $\mathrm{NO}_{3}-\mathrm{N}$ values.

Weekly measurements of $\mathrm{NO}_{3}-\mathrm{N}$ availability index in 2000 echoed the cumulative data in that the VR was lower than the UR (Fig. Ib). The average $\mathrm{NO}_{3}-\mathrm{N}$ availability index across the whole growing season for both the surface and subsurface depths was significantly lower in the VR treatment $(P$ $=0.0029$ and 0.0090 , respectively). For the shorter season variety Shepody, this data shows that there was less $\mathrm{NO}_{3}-\mathrm{N}$ available in the soil profile for leaching with the VR treatment.

In 1999 and 2000 surface cumulative PRS $\mathrm{NO}_{3}-\mathrm{N}$ availability index was significantly affected only by fertilizer treatment. However, in 2000 , the subsurface cumulative $\mathrm{NO}_{3}-\mathrm{N}$ availability index was significantly affected by SOM $(P=0.0635)$, landscape position (LP) $(P=0.0682)$, and the interaction of fertilizer treatment (FT) and SOM $(P=0.0818)$. The 2000 cumulative $\mathrm{PRS} \mathrm{NO}_{3}-\mathrm{N}$ availability index was significantly higher under UR and high SOM than the other interactions for FT and SOM (Fig. 2). This indicates that high organic matter content contributed to the increase in $\mathrm{NO}_{3}$ $\mathrm{N}$ available for plant uptake as well as nitrate leaching potential under UR, but not under VR.

Across both fertilizer treatments, the cumulative $\mathrm{NO}_{3}-\mathrm{N}$ availability index was highest in the slope position in $2000(P=0.0682)$ at $346.6 \mathrm{ppm}$ compared to $267.5 \mathrm{ppm}$ for the knoll and $212.3 \mathrm{ppm}$ for the valley positions. Since $\mathrm{NO}_{3}-\mathrm{N}$ availability reflects the concentration of $\mathrm{NO}_{3}-\mathrm{N}$ in the soil solution, the high values found in the slope position likely reflect heavy irrigation moving $\mathrm{NO}_{3}-\mathrm{N}$ laden water down slope. There was no effect of LP in 1999.

IN-SEASON TISSUE AND SOIL SAMPLES. Soil $\mathrm{NO}_{3}-\mathrm{N}$ concentration was significantly higher in the UR versus the VR fertilized fields in 1999 at two phenological stages, tuber initiation and tuber bulking, in both surface and subsurface soil depths (Table 1). Lang et al. (1999) suggest an optimal $\mathrm{NO}_{3}-\mathrm{N}$ range of 10 to 15 ppm during tuber initiation. While the average value for surface soil $\mathrm{NO}_{3}-\mathrm{N}$ at tuber initiation under the VR treatment was 
Table 1. Average soil (both surface and subsurface) and potato petiole nitrate-nitrogen ( $\mathrm{NO}_{3}-\mathrm{N}$ ) with uniform rate (UR) and variable rate $(\mathrm{VR})$ preplant $\mathrm{N}$ fertilizer management at two key phenological stages. 1 inch $=2.54 \mathrm{~cm}, 1 \mathrm{ppm}=1$ $\mathrm{mg} \cdot \mathrm{kg}^{-1}$.

\begin{tabular}{|c|c|c|c|c|c|c|}
\hline & \multicolumn{3}{|c|}{ Tuber initiation } & \multicolumn{3}{|c|}{ Tuber bulking } \\
\hline & \multicolumn{3}{|c|}{ Soil $\mathrm{NO}_{3}-\mathrm{N}(\mathrm{ppm})$} & \multicolumn{3}{|c|}{ Soil $\mathrm{NO}_{3}-\mathrm{N}(\mathrm{ppm})$} \\
\hline & $\begin{array}{c}0-12 \\
\text { inches }\end{array}$ & $\begin{array}{l}12-24 \\
\text { inches }\end{array}$ & $\begin{array}{l}\text { Petiole } \\
\mathrm{NO}_{3}-\mathrm{N} \\
(\mathrm{ppm})^{\mathrm{z}}\end{array}$ & $\begin{array}{c}0-12 \\
\text { inches }\end{array}$ & $\begin{array}{l}\text { 12-24 } \\
\text { inches }\end{array}$ & $\begin{array}{l}\text { Petiole } \\
\mathrm{NO}_{3}-\mathrm{N} \\
(\mathrm{ppm})^{\mathrm{z}}\end{array}$ \\
\hline \multicolumn{7}{|l|}{1999} \\
\hline UR & 27.8 & 12.3 & 17004 & 14.9 & 10.2 & 20314 \\
\hline VR & $\begin{array}{c}13.8 \\
P=0.0007\end{array}$ & $\begin{aligned} & 8 \\
P= & 0.0208\end{aligned}$ & $\begin{array}{c}15194 \\
P=0.0001\end{array}$ & $\begin{aligned} & 9.8 \\
P= & 0.0322\end{aligned}$ & $\begin{aligned} & 6.1 \\
P= & 0.0334\end{aligned}$ & $\begin{array}{c}18236 \\
P=0.0242\end{array}$ \\
\hline \multicolumn{7}{|l|}{2000} \\
\hline UR & 15.2 & 13.8 & 21313 & 10.4 & 10.3 & 18838 \\
\hline VR & $\begin{aligned} 9.7 \\
P=0.0951\end{aligned}$ & $\begin{array}{c}16.2 \\
\text { NS }\end{array}$ & $\begin{array}{c}19102 \\
P=0.0001\end{array}$ & $\begin{array}{l}12.7 \\
\text { NS }\end{array}$ & $\begin{array}{c}8.1 \\
P=0.0724\end{array}$ & $\begin{array}{c}13484 \\
P=0.0001\end{array}$ \\
\hline
\end{tabular}

${ }^{\mathrm{z}}$ Dry tissue.

within this range, the average surface soil $\mathrm{NO}_{3}-\mathrm{N}$ concentration of 27.8 ppm found under the UR treatment exceeded this range. The surface soil data suggest that excess $\mathrm{NO}_{3}-\mathrm{N}$ was available for leaching past the potato root zone under UR treatment.

At tuber initiation, in 2000, surface soil $\mathrm{NO}_{3}-\mathrm{N}$ concentration was significantly lower under VR treatment (Table 1). However, the average UR surface soil $\mathrm{NO}_{3}-\mathrm{N}$ was at the maximum recommended level (15 ppm) while in the VR treatment it was slightly below the minimum recommended concentration. Subsurface $\mathrm{NO}_{3}-\mathrm{N}$ did not significantly differ with fertilizer treatment at tuber initiation. Unlike in 1999, the subsurface soil $\mathrm{NO}_{3}-\mathrm{N}$ was higher underVR treatment, but did not exceed the recommended range.

At tuber bulking in 1999 the VR treatment average soil $\mathrm{NO}_{3}-\mathrm{N}$ concentration was near the recommended 10 ppm critical limit, while the UR average exceeded it (Table 1). In the subsurface soil, at both sampling times the UR treatment had significantly higher soil $\mathrm{NO}_{3}-\mathrm{N}$ concentration although it was not in excess at either sampling time (Table 1). The excess $\mathrm{NO}_{3}-\mathrm{N}$ found with the UR treatment implies there is a higher leaching potential than with the VR treatment. At tuber bulking in 2000, the surface $\mathrm{NO}_{3}-\mathrm{N}$ did not significantly differ with fertilizer treatment, but was near the maximum recommended concentration. Subsurface soil $\mathrm{NO}_{3}-\mathrm{N}$ depth was significantly higher under the UR treatment (Table 1). This finding late in the growing season implies there might be an increased $\mathrm{NO}_{3}-\mathrm{N}$ leaching potential under UR treatment.

Petiole $\mathrm{NO}_{3}-\mathrm{N}$ was significantly higher in the UR than the VR treatment at both sampling intervals in 1999 (Table 1). Under both fertilizer treatments petiole $\mathrm{NO}_{3}-\mathrm{N}$ was within the recommended concentration range at both tuber initiation ( 15,000 to 26,000 ppm) and tuber bulking (12,000 to 20,000 ppm) (Lang et al., 1999). Higher petiole $\mathrm{NO}_{3}-\mathrm{N}$ with UR fertilizer may be related to the higher soil $\mathrm{NO}_{3}-\mathrm{N}$ concentration values. Similar results were found in 2000 where the petiole $\mathrm{NO}_{3}-\mathrm{N}$ was significantly lower (Table 1) under VR treatment at both sampling times, yet within the recommended range.

Two potato varieties with vastly different growing seasons made it difficult to analyze the data with both years combined. There were a few significant results observed here. At tuber initiation the soil samples showed that there was significantly more soil $\mathrm{NO}_{3}-\mathrm{N}$ in the top 12 inches of the field with uniform fertilizer application $(P=$ $0.0004)$. This is what was seen in each individual analysis. Later in the season (tuber bulking) the soil $\mathrm{NO}_{3}-\mathrm{N}$ was significantly higher in the subsurface (12 to 24 inches) under uniform rate fertilizer application. Excess nitrate in the surface may have traveled with water movement to the subsurface later in the season, increasing the nitrate leaching potential under uniform fertilizer application. At both sampling times the petiole nitrate levels were significantly lower under variable rate fertilizer, which coincides with soil $\mathrm{NO}_{3}-\mathrm{N}$ levels found.

Postharvest soll samples. Postharvest surface soil samples taken to 12 inches in 1999 and 2000 had significantly higher average soil $\mathrm{NO}_{3}$ $\mathrm{N}$ concentration under VR treatment than under the UR treatment despite having lower soil $\mathrm{NO}_{3}-\mathrm{N}$ concentrations during the in season sample collections (Fig. 3). It is unclear why this occurred since the in-season soil samples and measured $\mathrm{NO}_{3}-\mathrm{N}$ availability index suggest that UR treatment had more available $\mathrm{NO}_{3}-\mathrm{N}$. Possible causes may be early season tissue deterioration or increase in excess irrigation at the end of the season. In 1999, due to higher levels of residual soil $\mathrm{N}$, VR had a higher potential postharvest $\mathrm{NO}_{3}-\mathrm{N}$ leaching.

\section{Conclusions}

Both early and late season potatoes grown under VR preplant fertilizer application had a lower nitrate availability index during the early growing season than those grown under UR. Less $\mathrm{NO}_{3}-\mathrm{N}$ was mobile and available for leaching. Petiole $\mathrm{NO}_{3}-\mathrm{N}$ concentration and surface soil $\mathrm{NO}_{3}-\mathrm{N}$ concentration was higher under UR at tuber

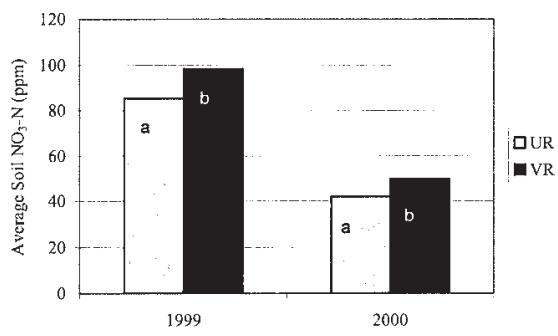

Fig. 3. Effect of preplant fertilizer treatment [UR (uniform rate), VR (variable rate)] on postharvest soil nitrate-nitrogen $\left(\mathrm{NO}_{3}-\mathrm{N}\right)$ concentrations $\left[\mathrm{ppm}\left(\mathrm{mg} \cdot \mathrm{kg}^{-1}\right)\right]$ in potato. Values are an average of the whole field postharvest soil samples at a sampling density of 1 sample/acre (2.47 samples/ha). Different letters on bars indicate statistically different values $\left(1.0\right.$ inch $\left.^{2}=6.45 \mathrm{~cm}^{2}\right)$. 
More research is required in specific potato varieties to determine the effectiveness of variable rate preplant fertilizer application. In the early part of the season, nitrate leaching potential appeared to have been reduced, but the effect did not appear to persist in the longer season variety. This suggests there may be carry over issues in the fall and winter following a long season variety. Only the preplant N was applied at variable rates with the remaining $60 \%$ of the in-season $\mathrm{N}$ applied uniformly. Thus, the site-specific preplant fertilizer application may have been masked by the in-season uniform $\mathrm{N}$ application throughout the prolonged 'Russet Burbank' growing season, resulting in $\mathrm{N}$ variability across the landscape to develop again. Site-specific application of in-season $\mathrm{N}$ fertilizer could reduce leaching potential further. In irrigated crops, fertigation can make this a possibility and should be explored further.

\section{Literature cited}

Anderson, N., and D.S. Humburg. 1997. Application equipment for site-specific management, p. 283-299. In: F.J. Pierce and E.J. Sadler (eds.). The state of sitespecific management for agriculture. ASA-CSSA-SSSA, Madison, Wis.

Dampney, P.M.R., G. Goodlass, M.A. Froment, and J.V.Stafford. 1999. Environmental and production effects from variable rate nitrogen fertilizer to winter wheat in england, p. 697-708. In: R.H. Rust, P.C. Robert, and W.E. Larson (eds.). Precision agriculture. 4th Intl. Precision Agr. Conf. ASA-CSSA-SSSA, Madison, Wis.

Errebhi, M., C.J. Rosen, S.C. Gupta, and D.E. Birong. 1998. Potato yield response and nitrate leaching as influenced by nitrogen management. Agron. J. 90:10-15.

Evans, R., S. Han, M.W. Kroeger, and S.M. Schneider. 1996. Precision center pivot irrigation for efficient use of water and nitrogen, p. 75-84. In: R.H. Rust, P.C. Robert, and W.E. Larson (eds.). Precision agriculture. 3rd Intl. Precision Agr. Conf. ASA-CSSA-SSSA, Madison, Wis.
Franzen, D.W., L.J. Cihacek, and V.L. Hofman. 1996. Variability of soil nitrate and phosphate under different landscapes. In: R.H. Rust, P.C. Robert, and W.E. Larson (eds.). Precision agriculture. 3rd Intl. Precision Agr. Conf. ASA-CSSA-SSSA, Madison, Wis.

Fuhrer, G., R.J. Gilliom, P.A. Hamilton, J.L. Morace, L.H. Nowell, J.F. Rinella, J.D. Stoner and D.A. Wentz. 1999. The quality of our nation's waters. USGS Circ. 1225, Reston, Va.

King, B.A., J.C. Start, and J.P. Taberna, Jr. 1999. In-season spatial variability of potato petiole nitrogen. In: R.H. Rust, P.C. Robert, and W.E. Larson (eds.). Precision agriculture. 4th Intl. Precision Agr. Conf. ASA-CSSA-SSSA, Madison, Wis.

Kitchen, N.R., D.F. Huges, K.A. Sudduth, and S.J. Birrell. 1995. Comparison of variable rate to single rate nitrogen fertilizer application: Corn production and residual soil $\mathrm{NO}_{3}-\mathrm{N}$, p. 427-44l. In: P.C. Robert et al. (eds.). Site-specific management for agricultural systems. ASA Misc. Publ. AASA-CSSA-SSSA, Madison, Wis.

Kunkel, R., and R.E. Thornton. 1986. Understanding the potato. Wash. State Univ., Pullman.

Lang, N.S., R.G. Stevens, R.E. Thornton, W.L. Pan, and S. Victory. 1999. Nutrient management guide: Central Washington irrigated potatoes. Wash. State Univ. Coop. Ext. 17.

Nolan, S., T.W. Goddard, D.C. Penny, and F.M. Green. 1999. Yield response to nitrogen within landscape classes, p. 479-485. In: R.H. Rust, P.C. Robert, and W.E. Larson (eds.) Precision agriculture. 4th Intl. Precision Agr. Conf. ASA-CSSA-SSSA, Madison, Wis.

Pan, W., and L.K. Hiller. 1992. Growth and development of potato root types: implications for placement and timing strategies in fertility management, $\mathrm{p}$. 105-111. Wash. State Potato Conf. and Trade Fair, Pullman.

Prunty, L. and R. Greenland. (1997). Nitrate leaching using two potato-corn $\mathrm{N}$-Fertilizer plans on sandy soil. Agr. Ecosystems, Environ. 65:1-13.
Redulla, C.A., J.R. Davenport, R.G. Evens, M.J. Hattendorf, A.K. Alva and R.A. Boydston. 2002. Relating potato yield and quality to field scale variability in soil characteristics. Amer. J. Potato Res. 79:317-323.

Roberts, S., and H.H. Cheng. 1985. Advances in nitrogen management for Russet Burbank potatoes, p. 41-47. In: Proceedings Wash. State Potato Conf. and Trade Fair, Pullman.

Roberts, S. and H.H. Cheng. 1988. Soil fertility and water management relationships in potato production, p. 19-25. In: Proceedings Wash. State Potato Conf. and Trade Fair, Pullman.

Roberts, S., R.N. Qubrosi and J.K. Rhee. 1991. Uptake and mobility of nutrients as influenced by potato irrigation, p. 57-63. In: Proceedings Wash. State Potato Conf. and Trade Fair, Pullman.

SAS Institute. 1996. SAS/STAT User's guide. Version 8.01. SAS Inst., Cary N.C.

Stalham, M. A. and E.J.Allen. 2001. Effect of variety, irrigation regime and planting date on depth, rate, duration and density of root growth in the potato (Solanum tubersum) crop. J. Agr. Sci. 137:251-270.

Qian, P., J.J. Schoenau, and W.Z. Huang. 1992. Use of ion exchange membranes in routine soil testing. Commun. Soil Sci. Plant Anal. 23:1791-1804.

Qian, P.and J.J. Schoenau. 2000. Use of ion exchange membrane to assess soil $\mathrm{N}$ supply to canola as affected by addition of liquid swine manure and urea. Can. J. Soil Sci. 80(1):213-218.

U.S. Environmental Protection Agency. 1984a. Methods for chemical analysis of water and wastes: Nitrogen ammonia. Method 350.1, STORET No. Total 00610, Dissolved 00608.

U.S. Environmental Protection Agency. 1984b. Methods for chemical analysis of water and wastes: Nitrogen nitratenitrite. Method 353.2, STORET No. Total 00630 .

Williamson, A.K., M.D. Munn, S.J. Ryker, R.J. Wagner, J.C. Ebbert, and A.M. Vanderpool. 1998. Water quality in the central columbia plateau. USGS Circ. 1144. 